\title{
Treatment Outcome of Pulmonary Tuberculosis Patients at Tehsil Head Quarter Hospital Dargai
}

\section{Tauseef Ahmad*}

Department of Microbiology, Hazara University, Khyber Pakhtunkhwa, Islamic Republic of Pakistan

Even in this modern era Tuberculosis (TB) poses a serious challenge for the world. Due to emerging of resistance strain and coinfection with Human Immuno Deficiency Virus (HIV)/Acquired Immuno Deficiency Syndrome (AIDS) it is difficult to control the disease. Among the 22 high TB burden countries Pakistan ranks $5^{\text {th }}$, in case of multi drug resistant its position is $27^{\text {th }}$ [1]. In the year 2013 , approximately 12997 incident cases of drug resistant TB in which only $1570(13 \%)$ were registered for treatment [2]. Aim of this study was to find out treatment success rate of pulmonary tuberculosis (PTB) at Tehsil Head Quarter Dargai, Khyber Pakhtunkhwa, Pakistan from $1^{\text {st }}$ January 2011 to $31^{\text {st }}$ December 2014. A total of 410 PTB patients were enrolled. Of the total cases, 373 (90.98\%) were diagnosed as new cases, $17(4.15 \%)$ were relapse cases, $13(3.17 \%)$ were transfer in cases, $7(1.7 \%)$ were others cases while no case of treatment failure and treatment default were recorded. The treatment success rate (cured and treatment completed) was reported $333(81.22 \%), 8(1.95 \%)$ cases were died from PTB, only $1(0.24 \%)$ case was failure, $2(0.49 \%)$ cases were default while $4(0.98 \%)$ were transfer out and $62(15.12 \%)$ cases were no record of treatment outcome (Table 1$)$.

Ahmad et al. [3] recorded 98.1\% treatment success rate at Civil Hospital Barikot Swat. Another study carried by Ahmad and Jadoon,

\begin{tabular}{|c|c|c|c|c|c|c|c|}
\hline Year & Total & C \& Rx & Died & Failure & Defaulted & TO & NR \\
\hline $\mathbf{2 0 1 1}$ & 98 & $92(93.88)$ & $2(2.04)$ & $1(1.02)$ & - & - & $3(3.06)$ \\
\hline $\mathbf{2 0 1 2}$ & 106 & $96(90.57)$ & $1(0.94)$ & - & $1(0.94)$ & $1(0.94)$ & $7(6.6)$ \\
\hline $\mathbf{2 0 1 3}$ & 106 & $86(81.13)$ & $3(2.83)$ & - & $1(0.94)$ & $3(2.83)$ & $13(12.26)$ \\
\hline $\mathbf{2 0 1 4}$ & 100 & $59(59)$ & $2(2)$ & - & - & - & $39(39)$ \\
\hline Total & 410 & $333(81.22)$ & $8(1.95)$ & 1 (0.24) & 2 (0.49) & 4 (0.98) & $62(15.12)$ \\
\hline
\end{tabular}

Table 1: Treatment outcome of registered PTB patients, $n$ (\%).
[4] at Thana District Malakand Pakistan reported $99.17 \%$ treatment success rate. A study conducted by Sunday et al. [5] at Ogbomoso, Southwestern Nigeria reported $85.5 \%$ treatment success rate, $95.1 \%$ patients treated with CAT- 1 and $4.9 \%$ treated with CAT- 11 treatment category. A study conducted by Getahun et al. [6] at Addis Ababa, Ethiopia reported $82.7 \%$ treatment success rate. Active case detection, proper treatment, awareness about $\mathrm{TB}$ is necessary to control and eliminate the disease. However, the treatment success rate was satisfactory and need more attention and intervention to get rid of this fatal disease.

\section{Acknowledgment}

The author acknowledges the support of THQ Hospital Dargai during the current study.

\section{References}

1. http://apps.who.int/iris/bitstream/10665/91355/1/9789241564656_eng.pdf

2. (2013) Routine National TB Control Program Data.

3. Ahmad T, Muhammad, Haroon, Majid A, Ullah N, et al. (2016) Treatment Outcomes of Suspected Tuberculosis Patients at Civil Hospital Barikot Swat Pakistan: (A Case Study). Sci Int (Lahore) 28: 423-425.

4. Ahmad T, Jadoon MA (2015) Cross Sectional Study of Pulmonary Tuberculosis at Civil Hospital Thana, District Malakand Khyber Pakhtunkhwa Pakistan. World J Zool 10: 161-167.

5. Sunday O, Oladimeji O, Ebenezer F, Akintunde B, Abiola T, et al. (2014) Treatment Outcome of Tuberculosis Patients Registered at DOTS Centre in Ogbomoso, Southwestern Nigeria: A 4-Year Retrospective Study. Tubercul Res Treat, pp: 1-5.

6. Getahun B, Ameni G, Medhin G, Biadgilign S (2013) Treatment outcome of tuberculosis patients under directly observed treatment in Addis Ababa, Ethiopia. Brazil J Infec Dis 17: 521-528.

Received January 23, 2017; Accepted January 25, 2017; Published January 27, 2017

Citation: Ahmad T (2017) Treatment Outcome of Pulmonary Tuberculosis Patients at Tehsil Head Quarter Hospital Dargai. Lung Dis Treat 3: 119. doi:10.4172/24721018.1000119

Copyright: () 2017 Ahmad T. This is an open-access article distributed under the terms of the Creative Commons Attribution License, which permits unrestricted use, distribution, and reproduction in any medium, provided the original author and source are credited. 